\title{
Erratum to: Antibiotic resistance and biofilm production among the strains of Staphylococcus aureus isolated in a tertiary care hospital in Nepal
}

\author{
Ankit Belbase ${ }^{1}$, Narayan Dutt Pant ${ }^{2}{ }^{*}$, Krishus Nepal $^{1}$, Bibhusan Neupane $^{1}$, Rikesh Baidhya $^{1}$, Reena Baidya $^{3}$ \\ and Binod Lekhak ${ }^{4}$
}

\section{Erratum to: Ann Clin Microbiol Antimicrob (2017) 16:15 \\ DOI 10.1186/s12941-017-0194-0}

The authors of this paper [1] would like to include some extra information regarding the methodology of this research. This information is provided below:

In the study, 830 various non-repeated clinical specimens were processed among which 76 (67 wound swab/pus samples, 5 catheter tips, 3 sterile body fluids and 1 tissue abscess) samples showed growth of $S$. aureus.

Appropriate changes to the text are listed below:

In the methods section of the abstract " 830 various non-repeated clinical specimens" should replace " 830 non-repeated pus/wound swab samples".

In the methods section "A total of 830 various clinical samples" should replace "A total of 830 pus/wound swab samples".

In the results section "Among total 830 various clinical samples processed" should replace "Among total 830 pus/ wound swab samples processed".

In the results section "Out of which, $S$. aureus was isolated from $76(20.9 \%)$ samples (67 wound swab/pus samples, 5 catheter tips, 3 sterile body fluids and 1 tissue abscess)" should replace "Out of which, S. aureus was isolated from 76 (20.9\%) samples".
The author has also proposed a revised title for the paper: "Antibiotic resistance and biofilm production among the strains of Staphylococcus aureus isolated in a tertiary care hospital in Nepal" which has been included as the title of this erratum.

\section{Author details \\ ${ }^{1}$ Department of Microbiology, GoldenGate International College, Battisputali, Kathmandu, Nepal. ${ }^{2}$ Department of Microbiology, Grande International Hos- pital, Dhapasi, Kathmandu, Nepal. ${ }^{3}$ Department of Pathology, B\&B Hospital, Gwarko, Lalitpur, Nepal. ${ }^{4}$ Central Department of Microbiology, Tribhuvan University, Kirtipur, Nepal.}

The online version of the original article can be found under doi:10.1186/s12941-017-0194-0.

\section{Publisher's Note}

Springer Nature remains neutral with regard to jurisdictional claims in published maps and institutional affiliations.

Received: 30 March 2017 Accepted: 4 April 2017

Published online: 13 April 2017

\section{Reference}

1. Belbase A, Pant ND, Nepal K, Neupane B, Baidhya R, Baidya R, Lekhak $B$. Antibiotic resistance and biofilm production among the strains of Staphylococcus aureus isolated in a tertiary care hospital in Nepal. Ann Clin Microbiol Antimicrob. 2017:16:15. doi:10.1186/s12941-017-0194-0.

*Correspondence: ndpant1987@gmail.com

${ }^{2}$ Department of Microbiology, Grande International Hospital, Dhapasi,

Kathmandu, Nepal

Full list of author information is available at the end of the article provided you give appropriate credit to the original author(s) and the source, provide a link to the Creative Commons license, and indicate if changes were made. The Creative Commons Public Domain Dedication waiver (http://creativecommons.org/ publicdomain/zero/1.0/) applies to the data made available in this article, unless otherwise stated. 